\title{
In vitro investigation of antioxidant activities of Launea taraxacifolia and Crassocephalum rubens
}

\author{
Funmilayo B. Borokini ${ }^{a^{*}}$ And Lajide Labunmi ${ }^{\mathrm{b}}$ \\ ${ }^{a}$ Department of Science Laboratory Technology, Rufus Giwa Polytechnic. P.M.B 1019, Owo, Ondo State \\ Nigeria \\ b Department of Chemistry, Federal University of Technology, Akure, P.M.B 704, Akure, Ondo State, Nigeria \\ * Corresponding author \\ borokinif59@yahoo.com \\ TEL: $+234(0) 8033358199$
}

Received: 19 October 2016; Published online: 18 April 2017

\begin{abstract}
Launea taraxacifolia and Crassocephalum rubens are among many wild, underutilized and under cultivated vegetables in Nigeria that are at risk of extinction. Total flavonoid contents (TFC), total phenolic contents (TPC), and antioxidant activities of different concentrations (1-5 mg ml ${ }^{-1}$ ) were evaluated; using in vitro assays to assess the scavenging properties of 2, 2-diphenyl-1-picryl hydrazyl (DPPHRSP), nitric oxide (NORSP) and hydroxyl (OHRSP). Phenolic profiles of the alcoholic extracts were characterized using high-performance liquid chromatography techniques. The results revealed higher TFC $(\mathrm{mg} / 100 \mathrm{~g} \mathrm{RE})$ in aqueous $(6.06 \pm 0.02-78.79 \pm 0.01)$ than alcohol extracts (with methanol $0.93 \pm 0.01-12.73 \pm 0.04$, and with ethanol $-0.85 \pm 0.01-7.70 \pm 0.03)$. In a similar trend, OHRSP (\%) was higher in aqueous extracts $(40.83 \pm 0.10-91.74 \pm 0.19)$ than alcoholic extracts (with methanol $11.67 \pm 0.3-30.83 \pm 0.06$; and with ethanol $-14.42 \pm 0.06-40.27 \pm 0.05)$. TPC (mg/100g GAE) which was higher in alcoholic extracts (with methanol $-21.48 \pm 0.01-133.20 \pm 0.16$ and with ethanol $-9.45 \pm 0.01-$ $59.73 \pm 0.02)$ than aqueous extracts $(14.83 \pm 0.01-52.64 \pm 0.03)$ was in agreement with the trend observed for NORSP (28.24 $\pm 0.05-151.76 \pm 0.08$ for methanolic extracts, $21.99 \pm 0.13-49.93 \pm 0.04$ for ethanolic extracts and 38.47 $\pm 0.11-86.15 \pm 0.05$ for aqueous extracts). DPPHRSP was also higher in alcoholic extracts (methanolic $-22.81 \pm 0.01-48.41 \pm 0.05$ and ethanolic-14.53 $\pm 0.01-62.68 \pm 0.07$ ) than aqueous extracts $(13.66 \pm 0.13-42.86 \pm 0.03)$. TFC, TPC and antioxidant activities showed concentration dependent increase and strong positive correlation with TFC $(\mathrm{r}=0.926-0.997$ and $\mathrm{r}=0.432-1.000)$ and TPC $(\mathrm{r}=0.825-0.999$ and $\mathrm{r}=0.473-0.994)$ for L. taraxacifolia and C. rubens respectively. Caffeic acid, chlorogenic acid, ellagic acid, quercetin and kaempferol were identified as major phenolic components in the extracts. The vegetables have high antioxidant potential for promoting good health; which could be attributed to the identified phytochemicals in them.
\end{abstract}

Keywords: Underutilized; Vegetables; Phenolic; Flavonoid; Antioxidant

\section{Introduction}

The antioxidant activity of fruits and vegetables is generally positively correlated with their content of polyphenols (Wang \& Lin, 2000; Koffi, Sea, Dodehe, \& Soro, 2010). Free radicals generated in living organism during various pro- cesses can cause extensive oxidative damage to cells during metabolism, leading to aging, cancer, neurodegenerative disorders, liver cirrhosis, atherosclerosis, diabetes, cardiovascular and other chronic diseases (Halliwell, 2007; Liu et al., 2010). Compounds such as vitamin C and $\mathrm{E}$, carotenoids and phenolics are natural antiox- 
idants that can slow or prevent this oxidative damage of other molecules thereby reducing the risk of diseases. The most effective antioxidants seem to be flavonoids and phenolic compounds of many plant raw materials, particularly in fruits, vegetables, herbs and seeds as many studies have suggested (Kim, Tsao, Yang, \& Cui, 2006; Adom \& Liu, 2002). Their metal-chelating capabilities and radical-scavenging properties have enabled phenolic compounds to be thought of as effective free radical scavengers and inhibitors of lipid peroxidation (Aruoma, 1998; Aruoma et al., 1997; Liu et al., 2010; Geng, Ren, Liu, \& X., 2012). Many wild plants exist in Nigeria but are underutilized probably due to inadequate knowledge of their health promoting potential and sometimes due to dietary habit.

L. taraxacifolia and C. rubens are among many underutilized wild vegetables in western Nigeria. While Crassocephalum rubens is used as a vegetable by few, especially among the aged and rural dwellers, L. taraxacifolia is not yet recognized as food and cannot be found in any market in Ondo State, the part of Nigeria where this work was carried out. Launaea taraxacifolia, also known as wild lettuce belongs to the family Asteraceae. The leaf is used as a vegetable in some parts of South-Western Nigeria in West Africa where it is called efo yanrin and research has established its high nutritional and medicinal values (Adebisi, 2004). It is mostly collected from the wild and only cultivated to a limited extent for home use and for local markets; whereas, it is known only as a weed in many parts of Nigeria. L. taraxacifolia is nutritionally rich in vitamins, minerals, proteins, essential fatty acids, fibre content and flavonoids (Adinortey et al., 2012; Dickson et al., 2012; Gbadamosi \& Sulaiman, 2012). Crassocephalum rubens (Juss. Exjacq. S. Moore) belongs to the plant family Asteraceae. It is a wild, economic and medicinal plant that is now threatened by genetic erosion in the Nigerian ecosystem. The scarcity of the plant is due to indiscriminate collection from the wild and the difficulty in germinating the seeds (Gbadamosi \& Sulaiman, 2012).

Many researchers have reported the nutritional values of $L$. taraxacifolia and $C$. rubens, with the aim of drawing attention to them, but there is a dearth of information on their antioxidant potentials. The present study was aimed at investigating phenolic composition and antioxidant activities of the different concentrations of aqueous and alcoholic extracts of the leaves of the above mentioned vegetables.

\section{Materials and Methods}

\subsection{Sample collection}

L. taraxacifolia was obtained from a nearby bush in Akure and C. rubens was purchased from a local market also in Akure, Ondo State, in Nigeria. Approximately $500 \mathrm{~g}$ was obtained for each.

\subsection{Preparation of Samples and extracts}

The air-dried vegetable samples were ground and sieved to give a $40 \mathrm{~mm}$ mesh size powder. A bioactive extract of each powdered vegetable was obtained by weighing $20 \mathrm{~g}$ into clean and dried reagent bottles, separately adding $400 \mathrm{~mL}$ of distilled water, methanol and ethanol into each bottle and subjecting them to a cold maceration process for $24 \mathrm{~h}$ to obtain the aqueous extract and $72 \mathrm{~h}$ to obtain the alcoholic extracts. Extracts were brought to dryness with a rotary evaporator at a low temperature $\left(45^{\circ} \mathrm{C}\right)$ and were kept at $3{ }^{\circ} \mathrm{C}$ in the refrigerator while the analyses were carried out (Iwalewa et al., 2005).

\subsection{Quantification of alcohol extracts by HPLC-DAD}

Chromatographic analyses were carried out under gradient conditions using a $\mathrm{C}_{18}$ column $(4.6 \mathrm{~mm} \times 250 \mathrm{~mm})$ in reverse phase (HPLCDAD with a Shimadzu Prominence Auto Sampler (SIL-20A) HPLC system, by Shimadzu, Kyoto, Japan), packed with $5 \mu \mathrm{m}$ diameter particles, where the mobile phase was water containing $1 \%$ acetic acid (A) and methanol (B), and the composition gradient was: $5 \%$ of $\mathrm{B}$ until 10 min and changed to obtain $20 \%, 30 \%, 50 \%, 60 \%$, $70 \%, 20 \%$ and $10 \% \mathrm{~B}$ at $20,30,40,50,60,70$ and $80 \mathrm{~min}$, respectively, following the method described by da Silva et al. (2014) with slight 
84| Borokini and Labunmi

modifications. Each extract of L. taraxacifolia and $C$. rubens was analyzed at a concentration of $20 \mathrm{mg} / \mathrm{mL}$. The samples and mobile phase were filtered through a $0.45 \mu \mathrm{m}$ membrane filter (Millipore) and then degassed by ultrasonic bath prior to use. The flow rate was $0.6 \mathrm{~mL} / \mathrm{min}$, injection volume $50 \mu \mathrm{L}$ and the wavelengths were 270 for gallic acid, $278 \mathrm{~nm}$ for coumarin, $327 \mathrm{~nm}$ for chlorogenic acid and caffeic acid, and $365 \mathrm{~nm}$ for quercetin, quercitrin, kaempferol and rutin. Chromatography peaks were confirmed by comparing their retention time with those of reference standards and by DAD spectra (200 to 500 $\mathrm{nm})$. Calibration curves were as follows for gallic acid: $\mathrm{Y}=13480 \mathrm{x}+1257.5(\mathrm{r}=0.9998)$; coumarin: $\mathrm{Y}=11983 \mathrm{x}+1196.9(\mathrm{r}=0.9997)$; chlorogenic acid: $\mathrm{Y}=11786 \mathrm{x}+1267.1(\mathrm{r}=$ 0.9991); caffeic acid: $\mathrm{Y}=13048 \mathrm{x}+1345.6(\mathrm{r}$ $=0.9995)$; rutin: $\mathrm{Y}=12478 \mathrm{x}+1194.9(\mathrm{r}=$ 0.9997), quercitrin: $\mathrm{Y}=13641 \mathrm{x}+1178.4(\mathrm{r}=$ 0.9997), kaempferol: $\mathrm{Y}=11458 \mathrm{x}+1269.4(\mathrm{r}=$ $0.9998)$ and quercetin: $\mathrm{Y}=12783 \mathrm{x}+1195.8(\mathrm{r}$ $=0.9996)$. All chromatography operations were carried out at ambient temperature and in triplicate.

The limit of detection (LOD) and limit of quantification (LOQ) were calculated based on the standard deviation of the responses and the slope using three independent analytical curves. LOD and LOQ were calculated as 3.3 and $10 \sigma / \mathrm{S}$, respectively, where $\sigma$ is the standard deviation of the response and $\mathrm{S}$ is the slope of the calibration curve (da Silva et al., 2014).

\subsection{Determination of total phenol contents}

The total phenol content (TPC) of the samples was determined by mixing $0.5 \mathrm{~mL}$ of each extract $\left(1-5 \mathrm{mg} \mathrm{mL}^{-1}\right)$ with $2.5 \mathrm{~mL} 10 \%$ FolinCioalteu's reagent $(\mathrm{v} / \mathrm{v})$ and $2.0 \mathrm{~mL}$ of $7.5 \%$ $\mathrm{Na}_{2} \mathrm{CO}_{3}$. The reaction mixture was subsequently incubated at $45{ }^{\circ} \mathrm{C}$ for $40 \mathrm{~min}$, and the absorbance measured at $760 \mathrm{~nm}$ by spectrophotometer. All tests were performed in triplicate. Gallic acid was used as a standard phenolic compound. The amount of total phenolic compounds in the extract was determined as $\mathrm{mg}$ of Gallic Acid Equivalent (GAE) per g dry weight (Sin- gleton, Orthofer, \& Lamuela-Raventos, 1999).

\subsection{Determination of total flavonoid}

A known volume (0.5 mL) of each extract (1-5 mg $\mathrm{mL}^{-1}$ ) was added to a $10 \mathrm{~mL}$ volumetric flask. Distilled water was added to make a volume of $5 \mathrm{~mL}$. At zero time, $0.3 \mathrm{ml}$ of $5 \% \mathrm{w} / \mathrm{v} \mathrm{NaNO}_{2}$ was added to the flask. After $5 \mathrm{~min}, 0.6 \mathrm{~mL}$ of $10 \% \mathrm{w} / \mathrm{v} \mathrm{AlCl}_{3}$ was added and after $6 \mathrm{~min}$, $2 \mathrm{~mL}$ of $1 \mathrm{M} \mathrm{NaOH}$ was added to the mixture followed by the addition of $2.1 \mathrm{~mL}$ distilled water. Absorbance was read at $510 \mathrm{~nm}$ against the blank (water) and flavonoid content expressed as mg Rutin equivalent/g. The test was carried out in triplicate (Zhishen, Mengcheng, \& Jianming, 1999).

\subsection{Determination of 2, 2-diphenyl-1-picryl hydrazyl (DPPH) radical scavenging ability}

Extracts of 1-5mg $\mathrm{mL}^{-1}$ each were mixed with $1 \mathrm{~mL}, 0.4 \mathrm{mM}$ methanolic solution containing DPPH radicals. The mixture was left in the dark for 30 min before measuring the absorbance at $516 \mathrm{~nm}$. This was carried out in triplicate (Zhishen et al., 1999). Percentage of inhibition $=\frac{A o-A 1}{A o} \times 100$, where Ao is the absorbance of the Trolox and A1 is the absorbance of the sample (Ursini, Maiorino, Morazzoni, Roveri, \& Pifferi, 1994). The percentage inhibition was plotted against the corresponding sample concentration $\left(1-5 \mathrm{mg} \mathrm{mL}^{-1}\right)$ and $\mathrm{IC}_{50}$ calculated from the graph equation.

\subsection{Determination of hydroxyl $(\mathrm{OH})$ radical scavenging activity}

The $\mathrm{OH}$ scavenging activity was determined by the method of Halliwell, Gutteridge, and Aruoma (1987). Exactly 1-5 mg mL ${ }^{-1}$ of each extract of the samples were mixed with $1 \mathrm{~mL}$ of reaction mixture $\left(100 \mu \mathrm{M} \mathrm{FeCl}_{3}, 104 \mu \mathrm{M}\right.$ Ethylene- 
diaminetetraacetic acid, $1.5 \mathrm{M} \mathrm{H}_{2} \mathrm{O}_{2}, 2.5 \mathrm{M}$ deoxyribose and $100 \mu \mathrm{M}$ ascorbic acid in $10 \mathrm{mM}$ $\mathrm{KH}_{2} \mathrm{PO}_{4}-\mathrm{KOH}, \mathrm{pH} 7.4$ ) and incubated for $1 \mathrm{~h}$ at $37{ }^{\circ} \mathrm{C}$. Thereafter, $1 \mathrm{~mL}$ of $0.5 \%$ thiobarbituric acid in $0.025 \mathrm{M} \mathrm{NaOH}$ and $1 \mathrm{~mL}$ of 2.8 $\%$ trichloroacetic acid was added to the mixture and heated for $30 \mathrm{~min}$ at $80{ }^{\circ} \mathrm{C}$ before reading the absorbance at $532 \mathrm{~nm}$ against an appropriate blank solution. All tests were performed in triplicate. Ascorbic acid was used as a positive control. Percent inhibition of $\mathrm{OH}$ was calculated by the following expression: Percentage of inhibition $=\frac{A o-A 1}{A o} \times 100$, where Ao is the absorbance of the Ascorbic acid and A1 is the absorbance of the sample. The percentage inhibition was plotted against corresponding sample concentration (1-5 $\mathrm{mg} \mathrm{mL}^{-1}$ ) and $\mathrm{IC}_{50}$ calculated from the graph equation.

\subsection{Determination of nitric oxide (NO) scavenging activity}

Briefly, $5 \mathrm{mM}$ sodium nitroprusside in phosphate-saline was mixed with different concentrations of the extracts: $1-5 \mathrm{mg} \mathrm{mL}^{-1}$, before incubation at $25^{\circ} \mathrm{C}$ for $150 \mathrm{~min}$. Thereafter, the reaction mixture was added to Greiss reagent ( $1 \%$ sulfanilamide, $2 \% \mathrm{H}_{3} \mathrm{PO}_{4}$ and 0.1 $\%$ naphthylethylenediamine dihydrochloride), before measuring the absorbance at $546 \mathrm{~nm}$ (Jagetia, Rao, Baliga, \& Babu, 2004). Ascorbic acid was used as the control. All tests were performed in triplicate. The nitric oxide radicals scavenging activity of the fractions was calculated according to the following equation: Percentage of inhibition $=\frac{A o-A 1}{A o} \times 100$, where Ao is the absorbance of Ascorbic acid and A1 is the absorbance in the presence of the fractions and ascorbic acid. The percentage inhibition was plotted against the corresponding sample concentration $\left(1-5 \mathrm{mg} \mathrm{mL} \mathrm{mL}^{-1}\right.$ ) and $\mathrm{IC}_{50}$ calculated from the graph equation.

\subsection{Determination of nitric oxide (NO) scavenging activity}

Values are presented as the mean $\pm \mathrm{SD}$ of three replicates. ANOVA and LSD and Pearson cor- relation analyses were performed using the commercial software SPSS 16.0

\section{Results and Discussion}

\subsection{Results}

\section{Phenolic compounds}

The HPLC profile of alcoholic extracts of Launea taraxacifolia revealed the presence of phenolic acids (gallic, caffeic, ellagic, and chlorogenic acids) and flavonoids (rutin, isoquercitrin, quercetin and kaempferol, coumarin, quercitrin and catechin) (Table 1, Figures 1 - 2).

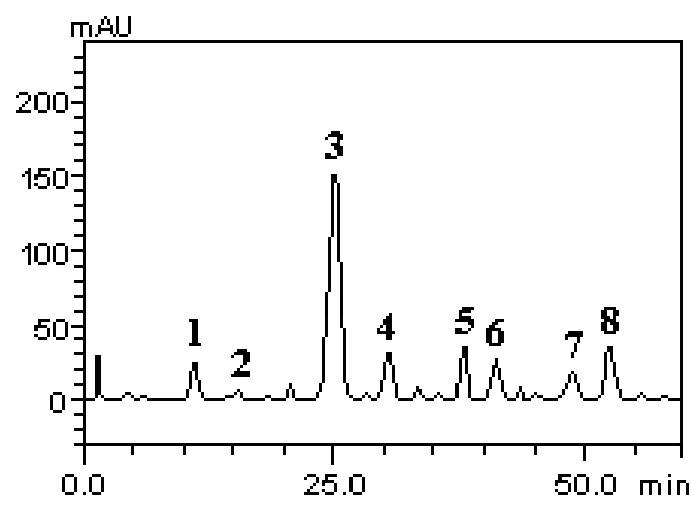

Figure 1: HPLC profile of a methanolic extract of Launea taraxacifolia. Gallic acid (peak 1), catechin (peak 2), caffeic acid (peak 3), ellagic acid (peak 4), rutin (peak 5), isoquercitrin (peak 6), quercetin (peak 7) and kaempferol (peak 8)

\section{Total phenol and total flavonoid contents}

TPC and TFC of L. taraxacifolia for all extracts were in the range 13.54-133.20 and 1.21- 78.79 $\mathrm{mg} / 100 \mathrm{~g}$ respectively, while TPC and TFC of $C$. ruben for all extracts were 9.45-81.64 and 0.85$60.61 \mathrm{mg} / 100 \mathrm{~g}$ respectively. The methanolic extracts of both vegetables contained the highest concentrations of TPC but the aqueous extracts gave the highest values for TFC. There was a positive and strong correlation between the antioxi- 
86 Borokini and Labunmi

Table 1: Phenolic compounds in the alcoholic extracts of the vegetables

\begin{tabular}{lllll}
\hline & \multicolumn{2}{c}{ Methanolic extracts } & \multicolumn{2}{c}{ Ethanolic Extracts } \\
\hline Compounds (mg/g) & L. taraxacifolia & C. ruben & L. taraxacifolia & C. ruben \\
\hline Gallic Acid & $10.95 \pm 0.03$ & $4.30 \pm 0.02$ & $0.37 \pm 0.01$ & $0.45 \pm 0.01$ \\
Chlorogenic Acid & $0 \pm 0.00$ & $50.91 \pm 0.01$ & $0.98 \pm 0.03$ & $0.91 \pm 0.01$ \\
Caffeic Acid & $72.30 \pm 0.01$ & $26.81 \pm 0.02$ & $4.35 \pm 0.03$ & $4.23 \pm 0.03$ \\
Caffeic Acid Derivative & $0 \pm 0.00$ & $12.76 \pm 0.01$ & $0 \pm 0.00$ & $0 \pm 0.00$ \\
Coumarin & $0 \pm 0.00$ & $0 \pm 0.00$ & $5.91 \pm 0.01$ & $4.37 \pm 0.02$ \\
Ellagic Acid & $18.67 \pm 0.01$ & $0 \pm 0.00$ & $0 \pm 0.00$ & $0 \pm 0.00$ \\
Catechin & $2.41 \pm 0.02$ & $0 \pm 0.00$ & $0 \pm 0.00$ & $0 \pm 0.00$ \\
Rutin & $19.53 \pm 0.03$ & $9.07 \pm 0.01$ & $3.47 \pm 0.02$ & $3.36 \pm 0.01$ \\
Isoquercitrin & $18.24 \pm 0.02$ & $27.15 \pm 0.03$ & $0 \pm 0.00$ & $0 \pm 0.00$ \\
Quercitrin & $0 \pm 0.00$ & $12.83 \pm 0.01$ & $3.69 \pm 0.01$ & $3.81 \pm 0.01$ \\
Quercetin & $12.07 \pm 0.03$ & $39.61 \pm 0.01$ & $6.03 \pm 0.01$ & $3.40 \pm 0.02$ \\
Kaempferol & $20.51 \pm 0.01$ & $8.42 \pm 0.02$ & $3.65 \pm 0.03$ & $3.95 \pm 0.01$ \\
\hline
\end{tabular}

Results are expressed as mean \pm standard deviations (SD) of three determinations

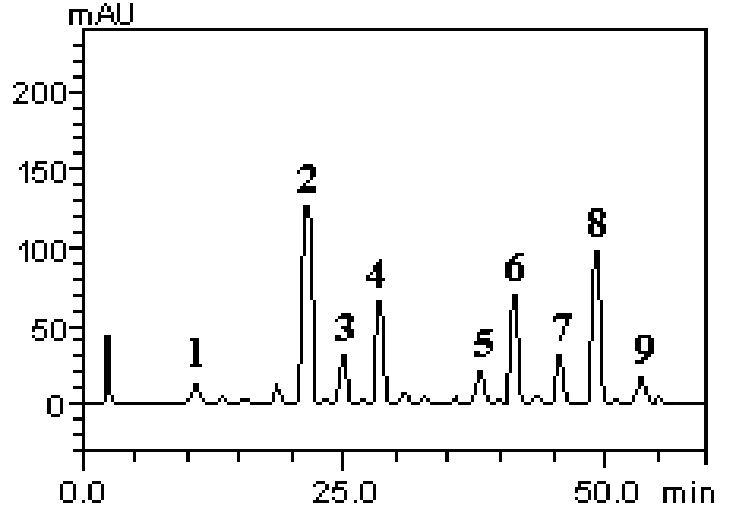

Figure 2: HPLC profile of a methanolic extract of Crassocephalum rubens. Gallic acid (peak 1), chlorogenic acid (peak 2), caffeic acid (peak 3 ), caffeic acid derivative (peak 4), rutin (peak 5 ), isoquercitrin (peak 6), quercitrin (peak 7), quercetin (peak 8) and kaempferol (peak 9) dant activities and the TFC and TPC (Tables 2, 3 and 4).

\section{DPPH Radical Scavenging Property}

The percentage inhibitions of DPPH in aqueous extracts were lower than in alcoholic extracts. All extracts demonstrated relatively appreciable concentration dependent increase, compared with Trolox (Tables $5-6$ ). $\mathrm{IC}_{50}$ values for free radicals are presented in Table 7 .

\section{Hydroxyl Radical Scavenging Property}

Aqueous extracts exerted a stronger scavenging capacity on $\mathrm{OH}$ in a dosage dependent manner than the alcoholic extracts and Ascorbic acid (Tables 5-6). The extracts showed significant in vitro antioxidant capacities.

\section{Nitric Oxide Radical Scavenging Property}

The percentage inhibition of NO was higher in methanolic extracts for both $L$. taraxacifolia and C. rubens than in aqueous extracts except at 1 $\mathrm{mg} \mathrm{mL} \mathrm{m}^{-1}$ concentrations. Aqueous extracts however exhibited stronger scavenging activity than 
Antioxidant Activities of two Nigerian underutilized vegetables $\mid 87$

Table 2: TFC and TPC of aqueous extracts $(\mathrm{mg} / 100 \mathrm{~g})$

\begin{tabular}{lllll}
\hline & Conc. $(\mathrm{mg} / \mathrm{ml})$ & $\begin{array}{l}\text { L. taraxacifolia } \\
\text { Aq. extracts }\end{array}$ & $\begin{array}{l}\text { C. rubens } \\
\text { Aq. extracts }\end{array}$ & $\begin{array}{l}\text { Reference standard } \\
\text { (Rutin/Gallic Acid) }\end{array}$ \\
\hline \multirow{4}{*}{$\mathrm{TFC}$} & 1 & $12.12^{b} \pm 0.01$ & $6.06^{a} \pm 0.02$ & $34.85^{c} \pm 0.03$ \\
& 2 & $21.21^{a} \pm 0.01$ & $21.21^{a} \pm 0.01$ & $63.64^{b} \pm 0.05$ \\
& 3 & $48.49^{b} \pm 0.03$ & $42.42^{a} \pm 0.05$ & $104.55^{c} \pm 0.14$ \\
& 4 & $63.64^{b} \pm 0.02$ & $51.52^{a} \pm 0.01$ & $136.36^{c} \pm 0.17$ \\
& 5 & $78.79^{b} \pm 0.01$ & $60.61^{a} \pm 0.03$ & $181.82^{c} \pm 0.06$ \\
& 1 & $24.71^{b} \pm 0.03$ & $14.83^{a} \pm 0.01$ & $275.97^{c} \pm 0.09$ \\
& 2 & $30.62^{b} \pm 0.02$ & $18.78^{a} \pm 0.01$ & $684.17^{c} \pm 0.11$ \\
& 3 & $34.38^{b} \pm 0.2$ & $30.71^{a} \pm 0.03$ & $1038.66^{c} \pm 0.08$ \\
& 4 & $47.27^{b} \pm 0.01$ & $41.55^{a} \pm 0.02$ & $1432.79^{c} \pm 0.15$ \\
& 5 & $52.64^{b} \pm 0.03$ & $50.08^{a} \pm 0.01$ & $1655.06^{c} \pm 0.12$ \\
\hline
\end{tabular}

Values represent means of triplicate readings $\pm \mathrm{SD}$. $(\mathrm{n}=3)$. Values with the same superscript along the row are not significantly different $(\mathrm{n}=3)$

Table 3: TFC and TPC of alcohol extracts $(\mathrm{mg} / 100 \mathrm{~g})$

\begin{tabular}{cclllll}
\hline & $\begin{array}{c}\text { Conc } \\
(\mathrm{mg} / \mathrm{ml})\end{array}$ & $\begin{array}{l}\text { L.taraxacifola } \\
\text { (Methanolic } \\
\text { Extract) }\end{array}$ & $\begin{array}{l}\text { C. rubens } \\
\text { (Methanolic } \\
\text { Extract) }\end{array}$ & $\begin{array}{l}\text { L.taraxacifola } \\
\text { (Ethanolic } \\
\text { Extract) }\end{array}$ & $\begin{array}{l}\text { C. ruben } \\
\text { (Ethanolic } \\
\text { Extract) }\end{array}$ & $\begin{array}{l}\text { Reference standard } \\
\text { (Rutin/Gallic Acid) }\end{array}$ \\
\hline & 1 & $1.21^{c} \pm 0.02$ & $0.93^{b} \pm 0.01$ & $1.76^{d} \pm 0.02$ & $0.85^{a} \pm 0.01$ & $34.85^{e} \pm 03$ \\
& 2 & $5.4^{d} \pm 0.01$ & $1.25^{a} \pm 0.01$ & $2.67^{c} \pm 0.01$ & $1.58^{b} \pm 0.01$ & $63.64^{e} \pm 0.05$ \\
$\mathrm{TFC}$ & 3 & $7.27^{d} \pm 0.01$ & $1.84^{a} \pm 0.01$ & $4.61^{c} \pm 0.02$ & $2.24^{b} \pm 0.02$ & $104.55^{e} \pm 0.14$ \\
& 4 & $10.91^{d} \pm 0.04$ & $4.85^{b} \pm 0.01$ & $5.88^{c} \pm 0.02$ & $3.15^{a} \pm 0.03$ & $136.36^{e} \pm 0.17$ \\
& 5 & $12.73^{d} \pm 0.04$ & $8.49^{c} \pm 0.01$ & $7.70^{b} \pm 0.03$ & $4.30^{a} \pm 0.03$ & $181.82^{e} \pm 0.06$ \\
& 1 & $38.67^{d} \pm 0.02$ & $21.48^{c} \pm 0.01$ & $13.54^{b} \pm 0.03$ & $9.45^{a} \pm 0.01$ & $275.97^{e} \pm 0.09$ \\
$\mathrm{TPC}$ & 2 & $51.56^{d} \pm 0.01$ & $34.38^{c} \pm 0.02$ & $24.06^{b} \pm 0.01$ & $18.91^{a} \pm 0.02$ & $684.17^{e} \pm 0.11$ \\
& 3 & $88.09^{d} \pm 0.02$ & $55.86^{c} \pm 0.02$ & $34.38^{b} \pm 0.01$ & $29.43^{a} \pm 0.02$ & $1038.66^{e} \pm 0.08$ \\
& 4 & $98.49^{d} \pm 0.01$ & $68.75^{c} \pm 0.01$ & $48.12^{b} \pm 0.04$ & $36.95^{a} \pm 0.04$ & $1432.79^{e} \pm 0.15$ \\
& 5 & $133.20^{d} \pm 0.16$ & $81.64^{c} \pm 0.03$ & $59.73^{b} \pm 0.02$ & $48.55^{a} \pm 0.03$ & $1655.06^{e} \pm 0.12$ \\
\hline
\end{tabular}

Values represent means of triplicate readings $\pm \mathrm{SD} .(\mathrm{n}=3)$. 
Table 4: Pearson's correlation coefficient between TFC, TPC and antioxidant assays

\begin{tabular}{llllll}
\hline & \multicolumn{3}{c}{ Samples } & \multicolumn{3}{c}{ Pearson correlation } \\
\hline \multirow{6}{*}{ Aqueous } & r value & & DPPH & OH & NO \\
& TFC & L. taraxacifolia & $.965^{* *}$ & $.989^{* *}$ & $.995^{* *}$ \\
& TPC & & $.995^{* *}$ & $.991^{* *}$ & $.945^{*}$ \\
& TFC & C. ruben & $.972^{* *}$ & $.907^{*}$ & $1.000^{* *}$ \\
Methanolic & TPC & & $.975^{* *}$ & $.962^{* *}$ & $.976^{* *}$ \\
& TFC & L. taraxacifolia & $.963^{* *}$ & $.985^{* *}$ & $.926^{*}$ \\
& TPC & & $.891^{*}$ & $.910^{*}$ & .825 \\
& TFC & C. ruben & $.966^{* *}$ & .846 & .432 \\
& TPC & & $.994^{* *}$ & $.895^{*}$ & .473 \\
& TFC & L. taraxacifolia & $.997^{* *}$ & $.958^{*}$ & $.996^{* *}$ \\
& TPC & & $.999^{* *}$ & $.952^{*}$ & $.994^{* *}$ \\
& TFC & C. ruben & $.990^{* *}$ & $.978^{* *}$ & $.978^{* *}$ \\
& TPC & & $.978^{* *}$ & $.957^{*}$ & $.994^{* *}$ \\
& & & $.965^{* *}$ & $.968^{* *}$ & $.987^{* *}$ \\
\hline \multirow{6}{*}{ Control } & & & & &
\end{tabular}

**Correlation is significant at 0.01 level (2-tailed), * Correlation is significant at 0.05 level (2-tailed).

Table 5: Antioxidant properties of the aqueous extracts (\%)

\begin{tabular}{|c|c|c|c|c|}
\hline $\begin{array}{l}\text { Samples concentrations } \\
\qquad(\mathrm{mg} / \mathrm{ml})\end{array}$ & & $\begin{array}{l}\text { L. taraxacifolia } \\
\text { Aq. Extracts }\end{array}$ & $\begin{array}{l}\text { C. rubens } \\
\text { Aq. Extracts }\end{array}$ & $\begin{array}{l}\text { Reference standard } \\
\text { Trolox/Ascorbic acid }\end{array}$ \\
\hline 1 & & $14.48^{b} \pm 0.04$ & $13.66^{a} \pm 0.13$ & $53.65^{c} \pm 0.05$ \\
\hline 2 & & $19.23^{a} \pm 0.01$ & $20.77^{b} \pm 0.02$ & $63.49^{c} \pm 0.05$ \\
\hline 3 & DPPHRSP & $23.10^{a} \pm 0.05$ & $25.87^{b} \pm 0.07$ & $77.86^{c} \pm 0.01$ \\
\hline 4 & & $34.64^{a} \pm 0.05$ & $36.65^{b} \pm 0.09$ & $81.58^{c} \pm 0.05$ \\
\hline 5 & & $42.86^{b} \pm 0.03$ & $37.85^{a} \pm 0.05$ & $92.38^{c} \mathrm{c} \pm 0.03$ \\
\hline 1 & & $40.83^{a} \pm 0.10$ & $52.34^{c} \pm 0.03$ & $47.64^{b} \pm 0.02$ \\
\hline 2 & & $49.58^{a} \pm 0.10$ & $58.54^{c} \pm 0.02$ & $54.28^{b} \pm 0.06$ \\
\hline 3 & OHRSP & $60.42^{a} \pm 0.03$ & $63.43^{b} \pm 0.05$ & $67.44^{c} \pm 0.03$ \\
\hline 4 & & $74.17^{c} \pm 0.06$ & $73.64^{b} \pm 0.17$ & $72.47^{a} \pm 0.01$ \\
\hline 5 & & $86.67^{b} \pm 0.04$ & $91.74^{c} \pm 0.19$ & $75.48^{a} \pm 0.04$ \\
\hline 1 & & $38.47^{a} \pm 0.11$ & $39.44^{b} \pm 0.11$ & $52.68^{c} \pm 0.11$ \\
\hline 2 & & $45.85^{a} \pm 0.19$ & $51.28^{b} \pm 0.03$ & $55.88^{c} \pm 0.02$ \\
\hline 3 & NORSP & $69.18^{b} \pm 0.01$ & $68.57^{a} \pm 0.17$ & $69.77^{c} \pm 0.01$ \\
\hline 4 & & $77.66^{c} \pm 0.02$ & $76.33^{b} \pm 0.04$ & $72.87^{a} \pm 0.01$ \\
\hline 5 & & $86.15^{c} \pm 0.05$ & $83.90^{b} \pm 0.19$ & $75.76^{a} \pm 0.02$ \\
\hline
\end{tabular}

Values represent means of triplicate readings \pm SD. Values with the same $(n=3)$. 
Antioxidant Activities of two Nigerian underutilized vegetables $\mid 89$

Table 6: Antioxidant properties of the alcoholic extracts (\%)

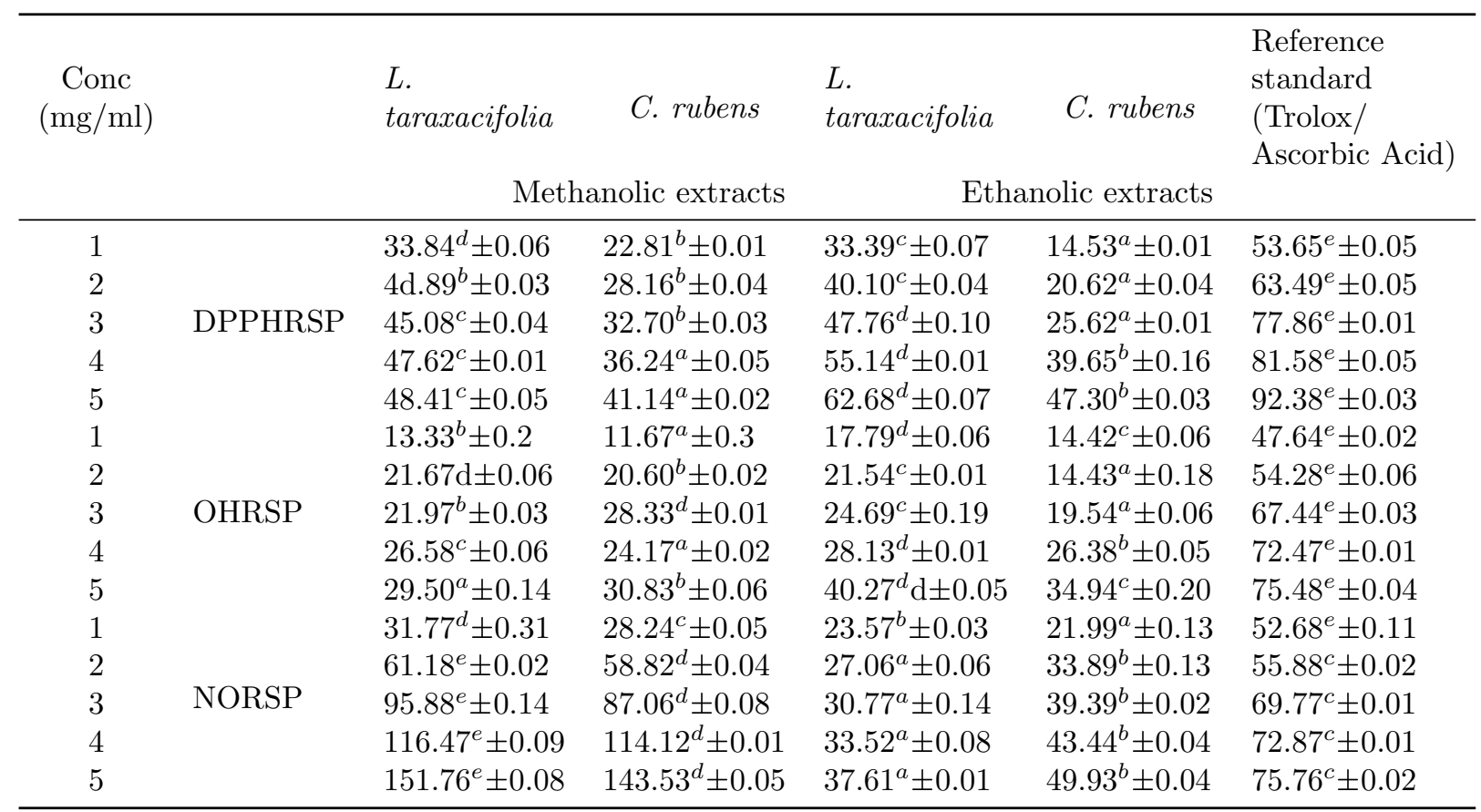

Values represent means of triplicate readings $\pm S D . \quad(n=3)$.

Table 7: $\mathrm{IC}_{50}$ values for free radicals in $\mathrm{mg} \mathrm{ml}^{-1}$

\begin{tabular}{|c|c|c|c|c|}
\hline Solvents & Samples & DPPH. $\mathrm{IC}_{50}$ & $\mathrm{OH} . \mathrm{IC}_{50}$ & NO. $\mathrm{IC}_{50}$ \\
\hline \multirow{2}{*}{ Aqueous } & L. taraxacifolia & 6.59 & 1.94 & 12.8 \\
\hline & C. ruben & 6.21 & 1.09 & 9.89 \\
\hline \multirow{2}{*}{ Methanolic } & L. taraxacifolia & 4.91 & 10.4 & 1.59 \\
\hline & C. ruben & 6.98 & 9.42 & 1.73 \\
\hline \multirow{2}{*}{ Ethanolic } & L. taraxacifolia & 3.29 & 2.46 & 4.88 \\
\hline & C. ruben & 5.42 & 2.91 & 8.65 \\
\hline \multirow{2}{*}{ Control } & & 0.51 & 1.18 & 0.56 \\
\hline & & TROLOX & VIT C & VIT C \\
\hline
\end{tabular}

\begin{tabular}{l|l|l|l} 
IJFS & April $2017 \mid$ Volume 6 & pages 82-94
\end{tabular} 
the ethanolic extracts. The antioxidant activities of all were appreciable, when compared with Ascorbic acid, a reference standard (Tables 5 $6)$.

\subsection{Discussion}

HPLC fingerprinting of methanolic and ethanolic extracts of $L$. taraxacifolia and C. rubens revealed the presence of phenolic acids; gallic acid and caffeic acid. Chlorogenic Acid which was the most abundant phenolic acid in the methanolic extract of $C$. rubens was absent only in the methanolic extract of $L$. taraxacifolia but detected in small concentrations in the ethanol extracts of both vegetables. Ellagic acid was, however, detected only in the methanolic extract of L. taraxacifolia while a caffeic acid derivative was also found only in the methanolic extracts of C. rubens. Rutin, quercetin and kaempferol are flavonoid compounds detected in methanolic and ethanolic extracts of both vegetables (Table 1). Phenolic compounds and flavonoids make up a unique category of plant phytochemicals especially in terms of their wide ranging potential health-benefial properties. In particular, phenolic compounds have been reported to modulate intracellular signaling, the activity of target enzymes and gene expression (Kumari \& Jain, 2012). Flavonoids have antioxidant activity and a range of health promoting effects such as antiallergic, anti-inflammatory, anti-thrombotic, vasoprotective, tumour inhibitory and anti-viral. These effects have been associated with the influence of flavonoids on the arachidonic acid metabolism (Ajiboye, Ibukun, Edobor, Ojo, \& Onikanni, 2013; Trease \& Evans, 2002). Isoquercitrin was detected in the methanolic but not in the ethanolic extracts of both L. taraxacifolia and C. rubens; whilst coumarin was found in ethanolic but not the methanolic extracts. Methanolic extracts of L. taraxacifolia lacked the presence of quercitrin but contained catechins which are powerful antioxidants that have been reported to cause reduction in glycemia (blood glucose levels) either by inhibiting intestinal glucose absorption (Shimizu, Kobayashi, Suzuki, Satsu, \& Miyamoto, 2000), inducing $\beta$ cell regeneration (Kim et al., 2003) or enhancing insulin activity (Anderson \& Polansky, 2002). Based on the findings here and in previous studies, $L$. taraxacifolia and C. rubens extracts may be of significant value in the management of diabetes mellitus.

TFC and TPC results revealed concentration dependent increase (Tables 2 and 3), and $L$. taraxacifolia for all extracts gave significantly $(p<0.05)$ higher values of TPC (13.54-133.20) than $C$. ruben (9.45-81.64). The methanolic extracts of both vegetables contained the highest concentrations of TPC. This was similar to the observation of Corpuz, Osi, and Santiago (2013) where aqueous extracts of S. siliquosum presented the lower amount of TPC in $\mathrm{mg} \mathrm{g}^{-1}$ than alcoholic extracts. TFC of L. taraxacifolia for all extracts were also significantly $(p<0.05)$ higher (1.21- $78.79 \mathrm{mg} / 100 \mathrm{~g})$ than C. ruben (0.85- 60.61 $\mathrm{mg} / 100 \mathrm{~g})$. The aqueous extracts of both however were significantly $(\mathrm{P}<0.05)$ higher than the alcoholic extracts in this study. The vegetables contained appreciable TPC and TFC though in significantly lower concentrations than gallic acid and rutin which were used as the standards in mg GAE/100g and RE/100g dry matter. 28.38 (mg GAE/g dry matter) and 0.97 (mg CTE/g dry matter) reported for TPC and TFC of methanolic extracts of $L$. taraxicofolia by Adetutu, Olorunnisola, and Oyewo (2013) were higher than 13.54-133.20 (mg GAE/100g) and 12.12- 78.79 (mg RE/100g) respectively obtained for the same vegetable in this study.

DPPH analysis demonstrates the ability of the vegetables under study to act as donors of hydrogen atoms as presented in Tables 5-6. Percentage inhibitions by the aqueous extracts were significantly $(p<0.05)$ lower than the alcoholic extracts, where the ethanolic extracts of both vegetables demonstrated the strongest scavenging power and L. taraxacifolia for all extracts exerted a significantly $(p<0.05)$ stronger scavenging power than $C$. Ruben. These are in agreement with the trend observed for TPC and supported by a strong and positive correlation between both TFC and TPC and DPPH at a 0.01- 0.05 level of significance (Table 4). 1 and $5 \mathrm{mg} \mathrm{mL}-1$ methanolic extracts of $C$. rubens gave 0 and 37.6 $\%$ DPPH scavenging activities in an earlier study by Iwalewa et al. (2005) which falls within the range of $22.8-41.1 \%$ obtained for the same ex- 
Antioxidant Activities of two Nigerian underutilized vegetables $\mid 91$

tract in this study. The Trolox standard exhibited significantly $(p<0.05)$ stronger inhibition than the extracts of vegetable. The $\mathrm{IC}_{50}$ value, which is inversely proportional to the antiradical activity, is the concentration of sample in $\mathrm{mg}$ $\mathrm{mL}^{-1}$ required for $50 \%$ scavenging of radicals. The $\mathrm{IC}_{50}$ values ranged from 3.30 in ethanolic extract of L. taraxacifolia to $6.98 \mathrm{mg} \mathrm{L}^{-1}$ in the methanolic extact of $C$. rubens. The extract using ethyl acetate of Crassocephalum bauchiense was reported to exhibit strong scavenging activity on $\mathrm{DPPH}$, with $\mathrm{IC}_{50}$ of $28.57-389.38$ $\mu \mathrm{g} \mathrm{mL}^{-1}$ for different fractions by Mouokeu, Ngono Ngane, Njateng, Kamtchueng, and Kuiate (2014).

The OH scavenging activity was measured by the ability of the extracts to scavenge the hydroxyl radicals generated by the $\mathrm{Fe}^{3+}$-ascorbate-EDTA$\mathrm{H}_{2} \mathrm{O}_{2}$ system in the Fenton reaction (Ilavarasan, Mallika, \& Venkataraman, 2006). The aqueous extracts exerted significantly $(p<0.05)$ stronger scavenging capacity on hydroxyl radicals in a dosage dependent manner than the alcoholic extracts and ascorbic acid. High TFC of the aqueous extracts may be responsible since phenolic compounds of plants belong to different classes of phenols and vary in their antioxidant strengths. The results of this study clearly indicate a positively strong correlation between both TFC and TPC of the extracts and the anti-hydroxyl radical capacities of the extracts as shown in Table 4. The extracts contained a considerable amount of phenolics and possess significant in vitro antioxidant capacities (Tables $5-6$ ). The aqueous extract of $C$. ruben demonstrated the strongest inhibitory power against $\mathrm{OH}$ radical with an $\mathrm{IC}_{50}$ value of $1.09 \mathrm{mg} \mathrm{ml}^{-1}$, which was stronger than ascorbic acid used as a reference standard.

Although, nitric oxide plays a vital role in various inflammatory processes, high levels of these radicals are toxic to tissue and contribute to the vascular collapse, various carcinoma and ulcerative colitis (Rajan et al., 2011). The results of this study showed that the percentage inhibition was significantly $(\mathrm{p}<0.05)$ higher in methanolic extracts of both $L$. taraxacifolia and $C$. rubens than aqueous extracts except at $1 \mathrm{mg} / \mathrm{mL}$ concentrations. However, aqueous extracts exhibited stronger scavenging activity than the ethanolic extracts, which is also in line with the trend ob- served for TPC. All extracts of the vegetables compared favorably with vitamin $\mathrm{C}$ in their inhibitory effect on nitric oxide. The methanolic extract of $L$. taraxacifolia with an $\mathrm{IC}_{50}$ value of 1.60 exhibited the strongest anti-radical ability against nitric oxide in this study.

The ability of $L$. taraxacifolia and $C$. rubens to effectively inhibit free radicals $(\mathrm{OH}, \mathrm{NO}, \mathrm{DPPH})$ and their reducing properties in this study may be attributed to the presence of phenolic compounds with potent antiradical properties. These vegetables possess high antioxidant potential to boost the body antioxidants and protect humans against detrimental oxidative effects caused by free radicals (Shukla, Mehta, Bajpai, \& Shukla, 2009; Corpuz et al., 2013).

\section{Conclusions}

The results of this study clearly indicate that aqueous and alcoholic extracts of $L$. taraxacifolia and $C$. rubens possess significant in vitro antioxidant capacities. Generally, strong and positive associations were observed between antioxidant activities and the total phenolic content as well as the total flavonoids' content of the vegetable extracts, although the order of antioxidant potency of each extract evaluated by different models does not follow the same pattern. These observations were in agreement with several studies which associated phenolic compounds with antioxidant activity. The reported potential health benefits of $L$. taraxacifolia and $C$. rubens may be attributed to the considerable amount of various phenolic acids and flavonoids detected in them. L. taraxacifolia and C. rubens can therefore be viewed as potential health foods, and their cultivation and utilization should be encouraged.

\section{Acknowledgements}

I am grateful to Aline AugustiBoligon, and Margareth Linde Athayde, Department of Industrial Pharmacy, Federal University of Santa Maria, Santa Maria, Brazil and everyone who in some way has contributed to the successful completion of this work. 


\section{References}

Adebisi, A. A. (2004). Launaea taraxacifolia (willd.) amin ex c. jeffrey (O. A. Grubben G. J. H. \& Denton, Ed.). Prota 2: Vegetables/Légumes. [Cd-Rom]. Prota, Wageningen, Netherlands.

Adetutu, A., Olorunnisola, O. S., \& Oyewo, E. B. (2013). Phytochemical composition, antioxidant properties and antibacterial activities of five west-african green leafy vegetables. Canadian Journal of pure and applied science, 7(2), 2357-2362. Retrieved from http://www.cjpas.net/wp-content/ uploads / pdfs / $7 / 2$ / previous_previous_ issue_07.pdf

Adinortey, M. B., K., S. J., T., Q. E., A., W., A., A. C., W., E., \& J., O. (2012). Phytochemical screening, proximate and mineral composition of Launaea taraxacifolia leaves. Research Journal of Medicinal Plants, 6(2), 171-179. doi:10.3923/rjmp. 2012.171.179

Adom, K. K. \& Liu, R. H. (2002). Antioxidant activity of grains. Journal of Agricultural and Food Chemistry, 50(21), 6182-6187. doi:10.1021/jf0205099

Ajiboye, B. O., Ibukun, E. O., Edobor, G., Ojo, A. O., \& Onikanni, S. A. (2013). Qualitative and quantitative analysis of phytochemicals in senecio biafrae leaf. International Journal of Inventions in Pharmaceutical Sciences, 1(5), 428-432.

Anderson, R. A. \& Polansky, M. M. (2002). Tea enhances insulin activity. Journal of Agricultural and Food Chemistry, 50(24), 71827186. doi:10.1021/jf020514c

Aruoma, O. I. (1998). Free radicals, oxidative stress, and antioxidants in human health and disease. Journal of the American Oil Chemists Society, 75(2), 199-212. 1st Meeting of the European-Section of the AOCS on Oil Processing and Biochemistry of Lipids, DIJON, FRANCE, SEP 19-20, 1996. doi:10.1007/s11746-998-0032-9

Aruoma, O. I., Spencer, J. P. E., Warren, D., Jenner, P., Butler, J., \& Halliwell, B. (1997). Characterization of food antioxidants, illustrated using commercial garlic and ginger preparations. Food Chemistry, 60(2),
149-156. doi:10 . 1016 / S0308 - 8146(95) 00254-5

Corpuz, M. J. A. T., Osi, M. O., \& Santiago, L. A. (2013). Free radical scavenging activity of sargassum siliquosum j. g. agardh. International Food Research Journal, 20(1), 291-297. Retrieved from http://www.ifrj. upm . edu . my / 20 \% 20(01 ) \%202013 / $39 \%$ 20IFRJ\%2020\%20(01)\%202013\%20Mary\% 20(169).pdf

da Silva, A. R. H., Moreira, L. d. R., Brum, E. d. S., de Freitas, M. L., Boligon, A. A., Athayde, M. L., ... Brandao, R. (2014). Biochemical and hematological effects of acute and sub-acute administration to ethyl acetate fraction from the stem bark scutia buxifolia reissek in mice. Journal of Ethnopharmacology, 153(3), 908916. doi:10.1016/j.jep.2014.03.063

Dickson, R. A., Annan, K., Fleischer, T. C., Amponsah, I. K., Nsiah, K., \& Oteng, J. A. (2012). Phytochemical investigations and nutritive potential of eight selected plants from ghana. Journal of Pharmacy and $\mathrm{Nu}$ trition Sciences, 2, 172-177.

Gbadamosi, I. T. \& Sulaiman, M. O. (2012). In vitro growth and shoot production of seeds of crassocephalum rubens (juss. ex jacq.) s. moore (asteraceae). World Journal of Agricultural Sciences, 8(2), 193-197.

Geng, M., Ren, M., Liu, Z., \& X., S. (2012). Free radical scavenging activities of pigment extract from hibiscus syriacus l. petals in vitro. African Journal of Biotechnology, 11(2), 429-435. doi:10.5897/AJB11.3037

Halliwell, B., Gutteridge, J. M. C., \& Aruoma, O. I. (1987). The deoxyribose method a simple test-tube assay for determination of rate constants for reactions of hydroxyl radicals. Analytical Biochemistry, 165(1), 215-219. doi:10.1016/0003-2697(87)902223

Halliwell, B. (2007). Dietary polyphenols: good, bad, or indifferent for your health? Cardiovascular Research, 73(2), 341-347. doi:10. 1016/j.cardiores.2006.10.004

Ilavarasan, R., Mallika, M., \& Venkataraman, S. (2006). Anti-inflammatory and free radical scavenging activity of ricinus communis root extract. Journal of Ethnopharma- 
Antioxidant Activities of two Nigerian underutilized vegetables $\mid 93$

cology, 103(3), 478-480. doi:10.1016/j.jep. 2005.07.029

Iwalewa, E. O., Adewunmi, C. O., Omisore, N. O. A., Adebanji, O. A., Azike, C. K., Adigun, A. O., ... Olowoyo, O. G. (2005). Pro- and antioxidant effects and cytoprotective potentials of nine edible vegetables in southwest nigeria. Journal of Medicinal Food, 8(4), 539-544. doi:10.1089/jmf.2005. 8.539

Jagetia, G. C., Rao, S. K., Baliga, M. S., \& Babu, K. S. (2004). The evaluation of nitric oxide scavenging activity of certain herbal formulations in vitro: a preliminary study. Phytotherapy Research, 18(7), 561-565. doi:10. 1002/ptr.1494

Kim, K. H., Tsao, R., Yang, R., \& Cui, S. W. (2006). Phenolic acid profiles and antioxidant activities of wheat bran extracts and the effect of hydrolysis conditions. Food Chemistry, 95(3), 466-473. doi:10.1016/j. foodchem.2005.01.032

Kim, M. J., Ryu, G. R., Chung, J. S., Sim, S. S., Min, D. S., Rhie, D. J., .. . Jo, Y. H. (2003). Protective effects of epicatechin against the toxic effects of streptozotocin on rat pancreatic islets: in vivo and in vitro. Pancreas, 26(3), 292-299. doi:10 . $1097 / 00006676$ 200304000-00014

Koffi, E., Sea, T., Dodehe, Y., \& Soro, S. (2010). Effect of solvent type on extraction of polyphenols from twenty three ivorian plants. Journal of Animal and Plant Sciences (JAPS), 5(3), 550-558.

Kumari, M. \& Jain, S. (2012). Tannins: an antinutrient with positive effect to manage diabetes. Research Journal of Recent Sciences, $1(12), 70-73$.

Liu, Y. Z., Cao, Y. G., Ye, J. Q., Wang, W. G., Song, K. J., Wang, X. L., ... Deng, X. M. (2010). Immunomodulatory effects of proanthocyanidin a-1 derived in vitro from rhododendron spiciferum. $F i$ toterapia, 81(2), 108-114. doi:10.1016/j . fitote.2009.08.005

Mouokeu, R. S., Ngono Ngane, R. A., Njateng, G. S., Kamtchueng, M. O., \& Kuiate, J.-R. (2014). Antifungal and antioxidant activity of crassocephalum bauchiense (hutch.) milne-redh ethyl acetate extract and frac- tions (asteraceae). BMC Research Notes, 7(1), 244. doi:10.1186/1756-0500-7-244

Rajan, S., Mahalakshmi, S., Deepa, V. M., Sathya, K., Shajitha, S., \& Thirunalasundari, T. (2011). Antioxidant potentials of punica granatum fruit rind extracts. International Journal of Pharmacy and Pharmaceutical Sciences, 3(3), 82-88. Retrieved from http : / / www . ijppsjournal . com / Vol3Issue3/2158.pdf

Shimizu, M., Kobayashi, Y., Suzuki, M., Satsu, H., \& Miyamoto, Y. (2000). Regulation of intestinal glucose transport by tea catechins. Biofactors, 13(1-4), 61-65. 2nd International Conference on Food Factors (2nd ICoFF), KYOTO, JAPAN, DEC 12 17, 1999 .

Shukla, S., Mehta, A., Bajpai, V. K., \& Shukla, S. (2009). in vitro antioxidant activity and total phenolic content of ethanolic leaf extract of stevia rebaudiana bert. Food and Chemical Toxicology, 47(9), 2338-2343. doi:10.1016/j.fct.2009.06.024

Singleton, V. L., Orthofer, R., \& LamuelaRaventos, R. M. (1999). Analysis of total phenols and other oxidation substrates and antioxidants by means of folin-ciocalteu reagent. In L. Packer (Ed.), Oxidants and antioxidants, pt a (Vol. 299, pp. 152-178). Methods in Enzymology.

Trease, G. E. \& Evans, W. C. (2002). Pharmacognosy. 15th. (Chap. Phytochemicals, pp. 42-44, 221-229, 246-249, 304-306, 331-332, 391-393). London: Saunders Publishers.

Ursini, F., Maiorino, M., Morazzoni, P., Roveri, A., \& Pifferi, G. (1994). A novel antioxidant flavonoid (idb-1031) affecting molecular mechanisms of cellular activation. Free Radical Biology and Medicine, 16(5), 547553. doi:10.1016/0891-5849(94)90054-X

Wang, S. Y. \& Lin, H. S. (2000). Antioxidant activity in fruits and leaves of blackberry, raspberry, and strawberry varies with cultivar and developmental stage. Journal of Agricultural and Food Chemistry, 48(2), 140-146. doi:10.1021/jf9908345

Zhishen, J., Mengcheng, T., \& Jianming, W. (1999). The determination of flavonoid contents in mulberry and their scavenging ef- 
94 Borokini and Labunmi

fects on superoxide radicals. Food Chem-

istry, 64 (4), 555-559. doi:10.1016/S0308-

8146(98)00102-2

IJFS | April 2017 | Volume 6 | pages 82-94 